\title{
Distribution of clinical isolates obtained from sterile body fluids: a four-year retrospective data
}

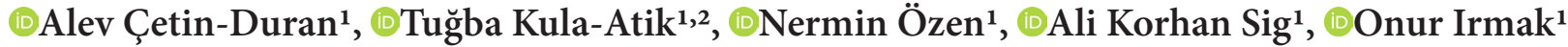 \\ ${ }^{1}$ Atatürk City Hospital, Department of Medical Microbiology, Balıkesir, Turkey \\ ${ }^{2}$ Balıkesir University, Faculty of Medicine, Department of Medical Microbiology, Balıkesir, Turkey
}

Cite this article as: Çetin-Duran A, Kula-Atik T, Özen N, Sig AK, Irmak O. Distribution of clinical isolates obtained from sterile body fluids: a four-year retrospective data. J Health Sci Med 2021; 4(6): 907-911.

\begin{abstract}
Aim: Infections of sterile body fluids (SBFs) require rapid and accurate diagnosis and treatment, since their morbidities and mortalities are high. To achieve this goal, definite epidemiologic data is absolutely required, since empiric and preemptive treatments are mainly based on this. The aim of this study was to evaluate infectious agents isolated from SBFs, susceptibility results and molecular analysis (PCR) data, retrospectively.

Material and Method: Clinical samples of SBFs (Cerebrospinal, pleural, peritoneal, pericardial and synovial fluids) obtained from January 2017 to December 2020 in Atatürk City Hospital (tertiary center) were included. Identification of bacterial and fungal agents and antibiotic susceptibility were done by conventional and automated system (BD Phoenix $x^{\mathrm{mm}}$, Becton Dickinson Co., Sparks, MD, USA). Löwenstein-Jensen media and BACTEC Mycobacteria Growth Indicator Tube 960 (Becton Dickinson Co., Sparks, MD, USA) were used for mycobacterial analysis. Bosphore Viral Meningitis Panel Multiplex PCR Kit (Anatolia Geneworks, İstanbul, Turkey) were applied to detect HSV-1, HSV-2, VZV, Enterovirus and/or Parechovirus.

Results: A total of 221 (9.74\%) organisms were detected among 2269 samples. Particularly common gram negative bacterial agents covered the top of the list (Escherichia coli, Pseudomonas spp., Klebsiella spp. and Acinetobacter baumanniiAcinetobacter calcoaceticus complex). Staphylococcus aureus was the most frequent gram positive strain, followed by enteroccocci. Most of the A. baumannii isolates were multidrug resistant, Pseudomonas spp. showed over than 20\% resistance rate to ceftazidime, cefepime and piperacillin-tazobactam. All enterococci were vancomycin-susceptible, one $S$. aureus strain was methicillin-resistant. All Mycobacterium tuberculosis complex isolates were found to be susceptible to first-line anti-tuberculosis drugs.

Conclusions: Continuous laboratory surveillance even in local phase is important to guide clinicians. Even though our data did not show significant changes, improvements on laboratory capabilities and clinical awareness must be done. Isolation rates might be underestimated due to requirement of improvements in our laboratory, especially about sampling, anaerobe transportation and usage of blood culture vials.
\end{abstract}

Keywords: Meningitis, pleuritis, infection, sterile body fluids

\section{INTRODUCTION}

Body fluids from sterile sites such as cerebrospinal (CSF), pleural, peritoneal, pericardial and synovial fluids are defined as sterile body fluids (SBFs). The crucial point from microbiologic view is that any growth on culture of these fluids is accepted as causative agent, except any suspicion of contamination. These samples are obtained via invasive procedures and preanalytic transportation to laboratories has great importance. Exact identification of microorganisms to at least genus level (preferably species level) directly guides clinicians to the appropriate treatment, even in the shortage of susceptibility tests.
Generally, a wide spectrum of microbiological analysis for SBFs is required, including bacterial, fungal, viral and mycobacterial agents (1-3).

Meningitis, pericarditis, pleural infection (either complicated parapneumonic effusion or empyema) and septic arthritis cover major forms of SBFs infections. The most frequent causative agents of these infections are Staphylococcus aureus, Streptococcus pneumoniae, Haemophilus influenza, Escherichia coli, Pseudomonas aeruginosa, Mycobacterium tuberculosis complex, Candida spp. and viruses $(2,3)$. Many factors including 
infection site, age, immune status and underlying pathologies have major effect on species epidemiology of etiologic agent. Diagnosis depends on several methods such as culture, PCR and serology (4-8).

Infections of $\mathrm{SBF}$ require rapid and accurate diagnosis and treatment, since their morbidities and mortalities are high. To achieve this goal, definite epidemiologic data is absolutely required, since empiric and preemptive treatments are mainly based on this. Furthermore, due to epidemiologic variations between geographic locations, local data of infections are crucial, since they create a base for national management guidelines. The aim of this study was to evaluate infectious agents isolated from SBFs, susceptibility results and molecular analysis (PCR) data, retrospectively.

\section{MATERIAL AND METHOD}

The study was carried out with the permission of Balikesir University Faculty of Medicine Clinical Researchs Ethics Committee (Date: 11.11.2020, Decision No: 2020/202). All procedures were carried out in accordance with the ethical rules and the principles of the Declaration of Helsinki.

Clinical samples of SBFs (CSF, pleural, peritoneal, pericardial and synovial fluids) obtained from January 2017 to December 2020 in Atatürk City Hospital (tertiary center) were included in the study. Identification of bacterial and fungal agents were done by conventional and automated system (BD Phoenix ${ }^{\mathrm{Tm}}$, Becton Dickinson Co., Sparks, MD, USA). Antibiotic susceptibility tests were also performed by the same system and evaluated according to "The European Committee on Antimicrobial Susceptibility Testing (EUCAST)" criteria (9). Antifungal susceptibility tests were not applied.

Mycobacterial analysis were performed by LöwensteinJensen (LJ) media (RTA Laboratories, Kocaeli, Turkey) and BACTEC "Mycobacteria Growth Indicator Tube" (MGIT) 960 (Becton Dickinson Co., Sparks, MD, USA) automated system. Susceptibility to the first-line antituberculosis drugs (Isoniazid-INH, rifampicin-RIF, ethambutol-ETM, streptomycin-SM) were also analyzed with the same system according to manufacturer's guidelines.

In patients with suspicion of viral meningitis, Bosphore Viral Meningitis Panel Multiplex PCR Kit (Anatolia Geneworks, İstanbul, Turkey) were applied to detect Herpes simplex virus-1 (HSV-1), Herpes Simplex Virus-2 (HSV-2), Varicella-Zoster Virus (VZV), Enterovirus (Coxsackie A ve B, Echovirus, Poliovirus and Enterovirus 68 - 71) and/or Parechovirus nuclear material.

\section{Statistical Analysis}

Retrospective definitive analysis was done. $\mathrm{n}$ (numbers) and ratios (\%) were shared. SPSS 22.0 (SPSS, IBM, Chicago, IL, USA) programme was used.

\section{RESULTS}

The majority of sterile samples were pleural fluid $(n=1105)$, followed by peritoneal fluid $(n=540)$, CSF $(n=440)$, synovial $(n=183)$ and pericardial fluid $(n=1)$, respectively. A total of 221 (9.74\%) agents were observed (157/540 in peritoneal fluid; 41/1105 in pleural fluid; 15/440 in CSF; 8/183 in synovial fluid and no isolation in pericardial fluid). Table 1 shows distribution of etiologic agents and ratios of isolated microorganisms. Bacterial strains had a dominance, particularly common gram negative bacterial agents covered the top of the list (Escherichia coli, Pseudomonas spp., Klebsiella spp. and Acinetobacter baumannii-Acinetobacter calcoaceticus complex). Staphylococcus aureus was the most frequent gram positive strain, followed by enteroccocci.

Most of the $A$. baumannii isolates were multidrugresistant (MDR) showing carbapenem resistance (90\%) and amikacin resistance $(60 \%)$, thus, colistin seemed to be the only therapeutic option (data not shown). On the other hand, Pseudomonas spp. showed over than 20\% resistance rate to ceftazidime, cefepime and piperacillintazobactam. All enterococci were vancomycinsusceptible, however one $S$. aureus strain was methicillinresistant (MRSA). Cephalosporin, fluoroquinolone and co-trimoxazole resistance were in seriously threatening levels for E. coli (over than 30\%). Table 2 shows antibiotic susceptibility results of $E$. coli, $K$. pneumoniae and Pseudomonas spp. All Mycobacterium tuberculosis complex isolates detected in SBFs were found to be susceptible to first-line anti-tuberculosis drugs.

\section{DISCUSSION}

Infections of SBFs are one of the most frequent infections in developing countries. The microorganism spectrum show extensive variation due to several factors such as antibiotic administrations, methodological differences and patient factors (underlying disease, surgeries, etc). In overall, K. pneumoniae, E. coli, $P$. aeruginosa, Citrobacter spp and Acinetobacterspp. are the most frequently isolated species among gram negative bacteria, while $S$. aureus, Streptococcus pneumoniae and enterococci are among gram positive ones. On the other hand, the question of the most common causative agent remains unanswered, since several studies indicated different results $(10,11)$.

Many experts and stewardship programs published different guidelines to manage and treat SBF infections, especially focusing on meningitis $(12,13)$. All these guides mainly depend on intensive antimicrobial therapies according to the causative agent. Thus, awareness of epidemiology even in local and/or national level directly affects the empiric and preemptive treatments, since epidemiological variations are severe. 


\begin{tabular}{|c|c|c|c|c|c|c|}
\hline $\begin{array}{l}\text { Types of infectious } \\
\text { agents } n(\%)\end{array}$ & Microorganism & $\begin{array}{c}\text { Overall } \\
\text { n }(\%)\end{array}$ & $\begin{array}{l}\text { Peritoneal fluid } \\
\text { n (\%) }\end{array}$ & $\begin{array}{l}\text { Pleural fluid } \\
\text { n (\%) }\end{array}$ & $\begin{array}{l}\text { CSF } \\
\text { n }(\%)\end{array}$ & $\begin{array}{c}\text { Synovial fluid } \\
\text { n (\%) }\end{array}$ \\
\hline \multicolumn{7}{|c|}{ Bacterial Agents $(n=234 ; 94.4 \%)$} \\
\hline & E. coli & $115(52.03)$ & $108(48.87)$ & $4(1.81)$ & $2(0.90)$ & $1(0.45)$ \\
\hline & Pseudomonas spp. & $25(11.31)$ & $16(7.23)$ & $8(3.62)$ & None & $1(0.45)$ \\
\hline & Klebsiella spp. & $17(7.69)$ & $13(5.88)$ & $2(0.90)$ & $2(0.90)$ & None \\
\hline & A. baumannii & $10(4.52)$ & $3(1.36)$ & $3(1.36)$ & $4(1.81)$ & None \\
\hline & S. aureus & $9(4.07)$ & $2(0.90)$ & $4(1.81)$ & None & $3(1.36)$ \\
\hline & Enterococcus spp. & $8(3.62)$ & $3(1.36)$ & $2(0.90)$ & $1(0.45)$ & $2(0.90)$ \\
\hline & S. maltophilia & $6(2.71)$ & $1(0.45)$ & $5(2.26)$ & None & None \\
\hline & S. pneumoniae & $4(1.81)$ & None & $3(1.36)$ & $1(0.45)$ & None \\
\hline & Group B Streptococci & $4(1.81)$ & $4(1.81)$ & None & None & None \\
\hline & Proteus spp. & $3(1.36)$ & $1(0.45)$ & $2(0.90)$ & None & None \\
\hline & Citrobacter spp. & $2(0.90)$ & $2(0.90)$ & None & None & None \\
\hline & Enterobacter spp. & $2(0.90)$ & $2(0.90)$ & None & None & None \\
\hline & Serratia spp. & $2(0.90)$ & $1(0.45)$ & None & $1(0.45)$ & None \\
\hline \multicolumn{7}{|c|}{ Mycobacterium spp. $(\mathrm{n}=6 ; 2.4 \%)$} \\
\hline & M. tuberculosis complex & $6(2.71)$ & None & $5(2.26)$ & None & $1(0.45)$ \\
\hline \multicolumn{7}{|c|}{ Fungal Agents $(n=6 ; 2.4 \%)$} \\
\hline & C. albicans & $3(1.36)$ & $1(0.45)$ & $1(0.45)$ & $1(0.45)$ & None \\
\hline & C. parapsilosis complex & $2(0.90)$ & None & $1(0.45)$ & $1(0.45)$ & None \\
\hline & C. tropicalis & $1(0.45)$ & None & $1(0.45)$ & None & None \\
\hline \multicolumn{7}{|l|}{ Viral Agents $(n=2 ; 0.8 \%)$} \\
\hline & HSV-1 & $2(0.90)$ & None & None & $2(0.90)$ & None \\
\hline & tal & $221(100.0)$ & $157(71.04)$ & $41(18.55)$ & $15(6.79)$ & $8(3.62)$ \\
\hline
\end{tabular}

\section{Table 2. Resistance rates of particular strains (\%) (Modified from references 15,18,19)}

\begin{tabular}{|c|c|c|c|c|c|c|c|c|c|c|c|}
\hline \multirow[b]{2}{*}{ 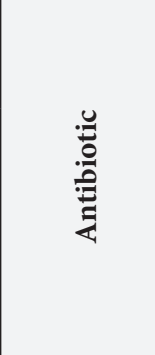 } & \multicolumn{3}{|c|}{ This Study } & \multicolumn{3}{|c|}{$\begin{array}{c}\text { CAESAR 2020 }^{\mathrm{b}} \\
\text { (R-Rate-\%) }\end{array}$} & \multicolumn{3}{|c|}{$\begin{array}{l}\text { EU/EEA Country Range } \\
\text { (R-Rate-\%) } \\
\text { (EARS-Net; 2015-2019) }\end{array}$} & \multicolumn{2}{|c|}{$\begin{array}{l}\text { SENTRY (R-Rate-\%) } \\
\text { (20-Year BSIs } \\
\text { Surveillance) }\end{array}$} \\
\hline & 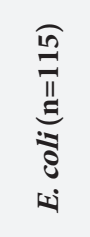 & 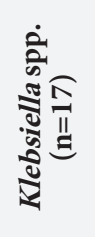 & 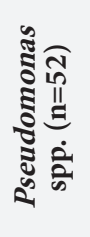 & รี & 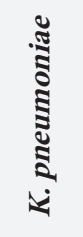 & 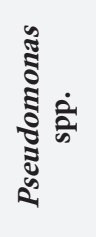 & غุ & 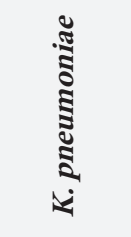 & 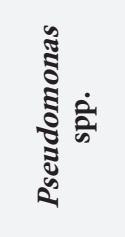 & 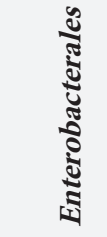 & 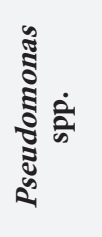 \\
\hline AK & None & 17.6 & 7.7 & 2.0 & 27.0 & 14.0 & ID & ID & ID & 1.3 & 7.6 \\
\hline $\mathrm{AG}^{\mathrm{c}}$ & 11.3 & 23.5 & NA & 26.0 & 45.0 & 21.0 & $4.7-24.4$ & $3.5-57.3$ & $0.3-48.9$ & 11.0 & 17.4 \\
\hline MEM & 2.6 & 29.4 & 36.5 & \multirow{2}{*}{3.0} & \multirow{2}{*}{39.0} & \multirow{2}{*}{38.0} & \multirow{2}{*}{$0.0-1.6$} & \multirow{2}{*}{$0.0-58.3$} & \multirow{2}{*}{$0.0-55.4$} & 1.0 & 16.3 \\
\hline IMP & 1.7 & 29.4 & 36.5 & & & & & & & 1.7 & 20.0 \\
\hline ERT & 11.3 & 35.3 & 51.9 & 9.0 & 51.0 & ID & ID & ID & ID & ID & ID \\
\hline CRO & 31.3 & 35.3 & 48.1 & 53.0 & 73.0 & ID & \multirow{2}{*}{$6.2-38.6$} & \multirow{2}{*}{$4.3-75.7$} & ID & 15.7 & ID \\
\hline CAZ & 28.7 & 35.3 & 42.3 & 47.0 & 70.0 & 28.0 & & & $3.5-52.2$ & ID & 17.4 \\
\hline FEP & 29.6 & 35.3 & 32.7 & ID & ID & 31.0 & ID & ID & ID & 7.7 & 10.1 \\
\hline $\mathrm{AMC}^{\mathrm{a}}$ & 45.2 & 41.2 & NA & 61.0 & 75.0 & ID & ID & ID & ID & ID & ID \\
\hline TZP & 6.1 & 35.3 & NA & 22.0 & 60.0 & 34.0 & ID & ID & $2.3-52.8$ & 5.6 & 14.9 \\
\hline TMP-SXT & 37.4 & 29.4 & NA & ID & ID & ID & ID & ID & ID & 25.3 & ID \\
\hline FQ & 24.3 & 35.3 & NA & 52.0 & 65.0 & 35.0 & $11.3-43.5$ & $4.3-66.9$ & $4.5-52.2$ & 17.5 & 23.0 \\
\hline
\end{tabular}


Some reports indicated that gram positive bacteria including $S$. pneumoniae and staphylococci showed a dominance, however, there are also studies stating gram negative superiority, like this study $(10,11,14)$. According to Central Asian and European Surveillance of Antimicrobial Resistance (CAESAR) report of Turkey, which included CSF and blood culture (BC) data, even though it was followed by Acinetobacter spp., $S$. pneumoniae had a few times more CSF isolation counts than the other strains. On the other hand, BC data seems to be different, since gram negative ones counted with a huge superiority (15). Contrary results were observed in a ten-year BC study from Turkey, since coagulase-negative staphylococci (CoNS) took the largest counts (16). The Turkish National Antimicrobial Resistance Surveillance System (UAMDSS) focuses on antimicrobial resistance (AMR) of $E$. coli, $K$. pneumoniae, $P$. aeruginosa, $S$. aureus, $S$. pneumoniae, Enterococcus faecium/faecalis and $A$. baumannii that were isolated from CSF and BCs. These strains were particularly under surveillance, since they were the most frequently isolated ones and they showed the most problematic resistance patterns (17). Of note, it is obvious that $\mathrm{BC}$ and other SBF data should be separated, because their microbiologic cultivation and management procedures are also different.

International antimicrobial stewardship programs supported by global organizations like World Health Organization (WHO), The Centers for Disease Control and Prevention (CDC) and The European Centre for Disease Prevention and Control (ECDC), and national authorities (Public Health Directorate of Turkey) specifically endorse a continuous surveillance on AMR, especially for particular species and infections. In this study, despite of only a limited data of pathogens were shared (Table 2), it can be observed that AMR is a serious issue for common species. The CAESAR, The SENTRY Antimicrobial Surveillance Program (20-Year bloodstream infections-BSIs data) and The European Antimicrobial Resistance Surveillance Network (EARSNet) data were also shared in Table $2(15,18,19)$. Although our sample size is much smaller and our data was based on samples other than BCs, our rates showed a slightly lower resistance profile, which might be explained with this sample differences. On the other hand, regarding EU/EEA Country Ranges in the EARS-Net data, it is obvious that our facility is in the "high-threat" zone (19). MDR rates of Acinetobacter spp., $\beta$-lactam resistance of Pseudomonas spp., cephalosporin, fluoroquinolone and co-trimoxazole resistance of $E$. coli were major observations. On the other hand, it is very promising that there was not any vancomycin-resistant enterococci (VRE) and MDR-tuberculosis cases, and there was only one MRSA strain, while UAMDSS and CAESAR reports stated opposite results $(15,17)$.
Recently, there are some reports that strongly recommended cultivation of SBFs with BC vials. Nowadays, there is a microbiological consensus that this method is very beneficial especially for reducing time to detection and increased growth ability of fastidious microorganisms $(20,21)$. In our facility, this technique is also recommended by our laboratory; however it is rarely preferred by clinicians. Thus, this might be a limitation of this study, since our isolation rates might have been underestimated. However, internationally-suggested methods are applied in our laboratory, so we believe this should be a minor effect. Another limitation is that anaerobic microbiological analysis cannot be performed in our laboratory due to physical issues. We believe anaerobes could also be causative agents in our infection profiles, but they were not able to be detected by our laboratory. Thirdly, we could not reach to any information of empiric and preemptive treatments applied to the patients and time of sampling. These patients generally required such kind of therapy, and time of sampling (before or after treatment) directly affects the isolation of the agent, especially for bacterial and fungal infections. If so, isolation rates might have also been underestimated.

\section{CONCLUSION}

Continuous laboratory surveillance even in local phase is important to guide clinicians. Data of this study did not seem to show any significant change in epidemiology, but it revealed that clinic and laboratory communication requires extensive improvement, especially about sampling, anaerobe transportation and usage of $\mathrm{BC}$ vials. Our laboratory also needs to focus on anaerobic cultivation methods. On the other hand, it is promising that any potential contaminant strain (E.g.; CoNS, gram positive rods) was not observed at any stage of cultivation. More data should be collected to modify national guidelines.

\section{ETHICAL DECLARATIONS}

Ethics Committee Approval: The study was carried out with the permission of Balıkesir University Faculty of Medicine Clinical Researchs Ethics Committee (Date: 11.11.2020, Decision No: 2020/202).

Informed Consent: Because the study was designed retrospectively, no written informed consent form was obtained from patients.

Referee Evaluation Process: Externally peer-reviewed.

Conflict of Interest Statement: The authors have no conflicts of interest to declare.

Financial Disclosure: The authors declared that this study has received no financial support. 
Author Contributions: All of the authors declare that they have all participated in the design, execution, and analysis of the paper, and that they have approved the final version.

\section{REFERENCES}

1. Özekinci T. Plevral sıvının mikrobiyolojik ve immünolojik analizi. Güncel Göğüs Hastalıkları Serisi 2015; 3: 316-8.

2. Öktem A, Çelik HT, Göçer E, Ceyhan M, Yiğit Ş, Yurdakök M. Yenidoğan döneminde septik artrit ve osteomiyelit: deneyimlerimiz ve güncel bilgilerin gözden geçirilmesi. Çocuk Sağlığı ve Hastalıkları Dergisi 2016; 59: 1-13.

3. Kleines M, Scheithauer S, Schiefer J, Häusler M. Clinical application of viral cerebrospinal fluid PCR testing for diagnosis of central nervous system disorders: a retrospective 11-year experience. Diagn Microbiol Infect Dis 2014; 80: 207-15.

4. Sayıner AA. Viral merkezi sinir sistemi infeksiyonlarında tanı. ANKEM Derg 2005; 19: 130-6.

5. Zeytinoğlu A, Erensoy S, Sertöz R, et al. Santral sinir sistemi enfeksiyonlarında viral etiyolojinin İzmir'de bir üniversite hastanesinin yedi ylllık verileri üzerinden değerlendirilmesi. Mikrobiyol Bul 2017; 51: 127-35.

6. Varıcı-Balcı FK, Sayıner AA. Viral etkenlere bağlı santral sinir sistemi enfeksiyonlarının yedi yıllık değerlendirmesi. Mikrobiyol Bul 2019;53: 434-41.

7. Akkaya O, Güvenç Hİ, Güzelant A, et al. Menenjit etkenlerinin Real-time PCR Yöntemiyle Araştırılması. Türk Mikrobiyol Cem Derg 2017; 47: 131-7.

8. Kahraman H, Tünger A, Şenol Ş, et al. Toplum kökenli santral sinir sistemi enfeksiyonlarında bakteriyel ve viral etiyolojinin moleküler yöntemlerle değerlendirilmesi. Mikrobiyol Bul 2017; 51: 277-85.

9. European Committee on Antimicrobial Susceptibility Testing (EUCAST). Breakpoint tables for interpretation of MICs and zone diameters. Version 11.0, Basel, Switzerland. https://www.eucast. org [Date of Access: 11 August 2021].

10. Tsegay E, Hailesilassie A, Hailekiros H, Niguse S, Saravanan M, Abdulkader M. Bacterial isolates and drug susceptibility pattern of sterile body fluids from tertiary hospital, Northern Ethiopia: a four-year retrospective study. J Pathog. 2019; 2019: 5456067.

11. Rouf M, Nazir A. Aerobic bacteriological profile and antimicrobial sensitivity pattern of bacteria isolated from sterile body fluids: A study from a Tertiary Care Hospital in North India. Microbiol Res J Int 2019; 28: 1-10

12. Young N, Thomas M. Meningitis in adults: diagnosis and management. Internal Med J 2018; 48: 1294-307.

13. Griffiths MJ, McGill F, Solomon T. Management of acute meningitis. Clin Med 2018 18: 164-9.

14. Poorabbas B, Mardaneh J, Rezaei Z, et al. Nosocomial Infections: Multicenter surveillance of antimicrobial resistance profile of Staphylococcus aureus and Gram negative rods isolated from blood and other sterile body fluids in Iran. Iran J Microbiol 2015; 7: 127-35

15. World Health Organization (WHO). Central Asian and European Surveillance of Antimicrobial Resistance (CAESAR), Annual 2020 Report, 2020. https://www.euro.who.int/_data/assets/pdf_ file/0003/469200/Central-Asian-and-European-Surveillance-ofAntimicrobial-Resistance.-Annual-report-2020-eng.pdf (Date of Access: 11 August 2021).

16. Mataj V, Guney M, Sig AK, et al. An Investigation into bacterial bloodstream infections and antibiotic resistance profiles in a tertiary hospital for a ten-year period. Clin Lab 2020; 66: 1467-77.

17. Ulusal Antimikrobiyal Direnç Sürveyans Sistemi. https://hsgm. saglik.gov.tr/tr/uamdss (Date of Access: 11 August 2021).
18. Diekema DJ, Hsueh PR, Mendes RE, et al. The microbiology of bloodstream infection: 20-year trends from the SENTRY antimicrobial surveillance program. Antimicrob Agent Chemother 2019; 63: e00355-19.

19.European Centre for Disease Prevention and Control. Antimicrobial resistance in the EU/EEA (EARS-Net) - Annual Epidemiological Report 2019. Stockholm: ECDC; 2020. https:// www.ecdc.europa.eu/en/publications-data/surveillanceantimicrobial-resistance-europe-2019 (Date of Access: 17 June 2021).

20.Sesli Çetin E, Kaya S, Demirci M, Cicioglu Aridogan B. Comparison of the BACTEC blood culture system versus conventional methods for culture of normally sterile body fluids. Adv Ther 2007; 24: 1271-7.

21. Udayan U, Dias M. Evaluation of BACTEC ${ }^{\mathrm{TM}}$ blood culture system for culture of normally sterile body fluids. Indian J Crit Care Med 2014; 18: 829-30. 